\title{
COMPARATIVE STUDY OF THE UDDER STRUCTURE IN BUFFALOES AND CATTLE: 1- MORPHOLOGICAL AND ANATOMICAL CHARACTERISTICS OF THE MAMMARY GLAND*
}

Safaa S. El-Ghousien ${ }^{1}$, G. Ashour ${ }^{2}$, M. M. Shafie ${ }^{2}$ and A. L. Badreldin ${ }^{2}$

1- Faculty of Agriculture and Science, Jerash Private University, Jerash, Jordan, 2Department of Animal Production, Faculty of Agriculture, Cairo University, Cairo, Giza, Egypt

\section{SUMMARY}

Twenty six Egyptian buffaloes and thirty Friesian cattle in adult age and comparable lactation number were used to study the morphological feature of the udder. The study comprised: circumference, fore and rear width; depth of front and rear quarters; longitudinal distance between the two fore teats and the two rear teats, alongside, the length and diameter of the teats. Anatomical comparative study was executed on the udder of Egyptian buffaloes and cattle and Friesian cattle, two from each, to find out any structural differences which could explain their species and breed differences in milk production. The anatomical studies comprised; teats structure (teat wall thickness, cistern and canal), gland cistern, vascular system (venous and arterial systems), and lymph glands. The morphological measurements increased with the progress in lactation number. Friesian udders showed wider distance between the two fore and the two rear teats, with larger width and depth and greater length of the udder than buffaloes. The rear teats were longer in buffaloes than in Friesians. However, the average length and diameter of the fore teats and the distance between the two fore teats and between the two rear teats were equal in both species. In both species, the measurements increased with the progress within the lactation season. Buffaloes possessed thicker teat wall, larger teat cistern, longer teat canal in comparison to cattle and a particular construction of the gland cistern showing pouches. Also, buffaloes showed more valves of the main venous system. The supramammary lymph gland was not lobulated in buffaloes. It could be concluded that the three types of animals express the same pattern in the structural functional relationship.

Keywords : Udder, morphology, anatomy, buffaloes, cattle.

\section{INTRODUCTION}

The morphological features of the bovine udder is, to a great extent, expressing the status (anatomy and activity) of its mammary glands. Suzuki et al. (1963) found significant positive correlations between 12 udder size features and milk yield for 118 Holestein cows. Hladky (1964) and Buben (1969) reported such positive relation in Czechoslovak Red Pied cows and in Russian cattle, respectively. The

${ }^{*}$ This paper was presented in the $53^{\text {rd }}$ Annual Meeting of the European Association for Animal Production (as an abstract).

Issued by The Egyptian Society of Animal Production 
morphological measures vary, extensively, between the bovine species and breeds, either in absolute values or relative to body weight. The apparent sizes of the udder quarters is related to their share in milk yield. In Egypt, Ragab et al. (1969) showed the following share (\%) of rear quarters in daily milk yield of Friesian, buffaloes and Egyptian cattle; 62, 69 and 58, respectively. The buffaloes show difference in the udder constitution between the different types and individuals. This lack of uniformity of quarters and teats causes difficulty in applying machine milking.

The present work was carried out to compare the morphological construction of Friesian cows and Egyptian buffaloes (reverine type) udders, alongside their general anatomical features in these species plus Egyptian cattle.

\section{MATERIALS AND METHODS}

This work was carried out in the Faculty of Agriculture, Cairo University, Egypt. The morphological study was executed on lactating cows; 30 Friesians and 26 buffaloes at different parities and lactation stages, as available in the Faculty farm and the farm of Faculty of Agriculture, Ain Shams University, Cairo. The measured features were; the udder circumference at conjunction with the abdominal skin, width and depth of fore and rear quarters, length and diameter of fore and rear teats, the cross distances between each fore and each rear teats, and the longitudinal distance between fores and rears.

The anatomical study was undertaken on 2 udders from each of Friesian, Egyptian buffaloes and cattle, one at early of lactation, the other at late lactation stages as defined in Table (1). Each udder was detached completely after slaughtering the cow without milking. To follow and demarcate the blood vessels, a colored (blue and red) gelatin solutions were injected through the anterior orifices of the subcutaneous abdominal vein and artery on both sides till the solutions appeared from the posterior orifices. A 10\% formol saline was injected through each teat canal, then all the udder was placed in the same solution for two days to harden the tissue and facilitate tracing the blood vessels. Bisection was operated from the tip of the teat till the gland cistern to define the pertaining structures.

\section{RESULTS AND DISCUSSION}

\section{I- Morphological characteristics of the udder: \\ 1-Udder measurements :}

At the same stage of lactation (5-7 mo.) in the $1^{\text {st }}$ parity, the Friesian possessed udders with larger width and depth in the fore and rear quarters than buffaloes (Table 1). The species difference in the circumference of the udder was in favour of buffaloes, this seems to be due to the great thickness of buffalo's skin causing lack of proper delineation of udder skin from abdomen skin. Garkavijs et al. (1965) found that the averages of udder circumference, depth and width in cattle were 90-100, 2227 and 22-29 cm, respectively. In both studied species, the measurements increased with the progress in parity (Tables 2 and 3), in agreement with Garkavijs et al. (1965) and Nowak (1969). 
Table 1. Morphological features of the udder of Friesians and buffaloes in the first lactation (parity) at identical lactation stages

\begin{tabular}{|c|c|c|c|c|c|c|}
\hline \multirow{3}{*}{$\begin{array}{l}\text { Cow } \\
\text { No. }\end{array}$} & \multirow{3}{*}{$\begin{array}{l}\text { Lactation stage } \\
\text { (month) }\end{array}$} & \multicolumn{5}{|c|}{ Measurements of the udder and quarters $(\mathrm{cm})$} \\
\hline & & \multirow{2}{*}{ Circumference } & \multicolumn{2}{|c|}{ Width } & \multicolumn{2}{|c|}{ Depth } \\
\hline & & & Fore & Rear & Fore & Rear \\
\hline \multicolumn{7}{|c|}{ Friesians } \\
\hline 1 & 5 & 72 & 25 & 16 & 15 & 21 \\
\hline 2 & 5 & 56 & 18 & 16 & 13 & 27 \\
\hline 3 & 7 & 50 & 17 & 18 & 7 & 20 \\
\hline 4 & 7 & 57 & 21 & 18 & 18 & 30 \\
\hline 5 & 7 & 63 & 23 & 16 & 17 & 28 \\
\hline 6 & 7 & 58 & 20 & 17 & 13 & 21 \\
\hline Mean & & 59 & 21 & 17 & 14 & 25 \\
\hline Range & & $50-72$ & $17-25$ & $16-18$ & $7-18$ & $20-30$ \\
\hline \multicolumn{7}{|c|}{ Buffaloes } \\
\hline 1 & 5 & 73 & 22 & 20 & 10 & 27 \\
\hline 2 & 5 & 73 & 15 & 18 & 11 & 24 \\
\hline 3 & 7 & 77 & 16 & 17 & 11 & 22 \\
\hline 4 & 7 & 74 & 14 & 13 & 10 & 25 \\
\hline 5 & 7 & 73 & 10 & 10 & 8 & 22 \\
\hline 6 & 7 & 82 & 16 & 12 & 7 & 25 \\
\hline Mean & & 75 & 16 & 15 & 10 & 24 \\
\hline Range & & $73-82$ & $10-22$ & $10-20$ & $7-11$ & $22-27$ \\
\hline
\end{tabular}

\section{2- Teat measurements :}

Teats measurements showed no difference between Friesians and buffaloes in length and diameter of the fore teats which averaged 6 and $2 \mathrm{~cm}$., respectively. The rear teats were longer in buffaloes than Friesians, 6.3 and $5.2 \mathrm{~cm}$., respectively (Tables 4 and 5). The Friesians had wider cross distance between the two fore and between the two rear teats than buffaloes 11.9 and 5.3 vs. 9.0 and $4.6 \mathrm{~cm}$., respectively. This wider spacing of the teats in Friesian is caused by the wider udder in this breed in comparison to buffaloes (Tables 4 and 5). In both species, the distance between the fore teats was double to that between the rear teats. Garkavijs et al. (1965) found in cattle that the average teat length and diameter were 6-9 and 2-3 $\mathrm{cm}$., respectively. 
Table 2. Morphological features of the udder of Friesians in the second and successive lactations (parity) at different lactation stages

\begin{tabular}{|c|c|c|c|c|c|c|c|}
\hline \multirow{3}{*}{$\begin{array}{l}\text { Cow } \\
\text { No. }\end{array}$} & \multirow{3}{*}{ Parity } & \multirow{3}{*}{$\begin{array}{c}\text { Lactation } \\
\text { Stage } \\
\text { (mon.) }\end{array}$} & \multicolumn{5}{|c|}{ Measurements of the udder and quarters $(\mathrm{cm})$} \\
\hline & & & \multirow{2}{*}{ Circumference } & \multicolumn{2}{|c|}{ Width } & \multicolumn{2}{|c|}{ Depth } \\
\hline & & & & Fore & Rear & Fore & Rear \\
\hline 1 & 2 & 3 & 64 & 25 & 21 & 15 & 31 \\
\hline 2 & 2 & 4 & 79 & 32 & 25 & 15 & 28 \\
\hline 3 & 2 & 4 & 71 & 31 & 21 & 14 & 33 \\
\hline 4 & 2 & 7 & 57 & 26 & 20 & 17 & 26 \\
\hline 5 & 2 & 7 & 77 & 23 & 13 & 16 & 30 \\
\hline 6 & 3 & 8 & 70 & 20 & 17 & 17 & 32 \\
\hline 7 & 3 & 9 & 76 & 31 & 19 & 15 & 35 \\
\hline 8 & 3 & 2 & 70 & 31 & 26 & 13 & 26 \\
\hline 9 & 4 & 1 & 60 & 21 & 16 & 17 & 33 \\
\hline 10 & 4 & 1 & 76 & 28 & 21 & 22 & 32 \\
\hline 11 & 4 & 3 & 78 & 26 & 21 & 15 & 35 \\
\hline 12 & 4 & 5 & 78 & 18 & 18 & 21 & 35 \\
\hline 13 & 5 & 8 & 77 & 25 & 20 & 20 & 30 \\
\hline 14 & 5 & 9 & 79 & 22 & 21 & 17 & 29 \\
\hline 15 & 5 & 5 & 74 & 22 & 18 & 21 & 31 \\
\hline 16 & 6 & 5 & 71 & 24 & 18 & 17 & 31 \\
\hline 17 & 6 & 6 & 72 & 27 & 21 & 17 & 35 \\
\hline 18 & 6 & 3 & 75 & 30 & 19 & 17 & 32 \\
\hline 19 & 7 & 5 & 70 & 21 & 20 & 12 & 31 \\
\hline 20 & 7 & 6 & 75 & 31 & 22 & 20 & 28 \\
\hline 21 & 7 & 10 & 80 & 32 & 31 & 20 & 27 \\
\hline 22 & 8 & 1 & 84 & 30 & 23 & 17 & 21 \\
\hline 23 & 8 & 1 & 94 & 31 & 19 & 27 & 29 \\
\hline 24 & 9 & 7 & 90 & 23 & 27 & 27 & 38 \\
\hline Mean & & & 75 & 26 & 21 & 18 & 31 \\
\hline Range & & & $57-94$ & $18-32$ & $13-31$ & $12-27$ & $21-38$ \\
\hline
\end{tabular}

Table 3. Morphological features of the udder of buffaloes in the second and successive lactations (parity) at different lactation stages

\begin{tabular}{|c|c|c|c|c|c|c|c|}
\hline \multirow{3}{*}{$\begin{array}{c}\text { Buff. } \\
\text { No. }\end{array}$} & \multirow{3}{*}{ Parity } & \multirow{3}{*}{$\begin{array}{l}\text { Lactation } \\
\text { stage } \\
\text { (mon.) }\end{array}$} & \multicolumn{5}{|c|}{ Measurements of the udder and quarters $(\mathrm{cm})$} \\
\hline & & & \multirow{2}{*}{ Circumference } & \multicolumn{2}{|c|}{ Width } & \multicolumn{2}{|c|}{ Depth } \\
\hline & & & & Fore & Rear & Fore & Rear \\
\hline 1 & 2 & 8 & 70 & 25 & 21 & 11 & 26 \\
\hline 2 & 5 & 5 days & 93 & 33 & 24 & 11 & 30 \\
\hline 3 & 5 & 1 & 97 & 31 & 22 & 12 & 30 \\
\hline 4 & 7 & 12 & 100 & 28 & 21 & 12 & 31 \\
\hline 5 & $>7$ & 3 & 67 & 29 & 20 & 10 & 33 \\
\hline Mean & & & 85.4 & 29.2 & 21.6 & 11.2 & 30.0 \\
\hline Range & & & $67-100$ & $25-33$ & $20-24$ & $10-12$ & $26-33$ \\
\hline
\end{tabular}


Table 4. Measurements of Friesian teats (cm)

\begin{tabular}{cccccccc}
\hline Cow & \multicolumn{2}{c}{ Fore teats } & \multicolumn{2}{c}{ Rear teats } & \multicolumn{3}{c}{ Distance between teats } \\
\cline { 2 - 8 } No. & Length & Diameter & Length & Diameter & Fore-Rear & Fores & Rears \\
\hline & & & & & & & \\
$\mathbf{1}$ & 6 & 1.6 & 5 & 1.2 & 5 & 11 & 5 \\
$\mathbf{2}$ & 6 & 1.8 & 3 & 1.4 & 3 & 10 & 4 \\
$\mathbf{3}$ & 8 & 2.0 & 5 & 2.0 & 3 & 10 & 5 \\
$\mathbf{4}$ & 7 & 1.5 & 8 & 2.0 & 3 & 7 & 3 \\
$\mathbf{5}$ & 6 & 2.0 & 4 & 2.0 & 3 & 8 & 3 \\
$\mathbf{6}$ & 6 & 1.6 & 5 & 1.6 & 3 & 11 & 6 \\
$\mathbf{7}$ & 6 & 2.0 & 5 & 2.2 & 4 & 13 & 7 \\
$\mathbf{8}$ & 6 & 2.2 & 4 & 1.8 & 5 & 12 & 6 \\
$\mathbf{9}$ & 5 & 1.8 & 5 & 1.9 & 6 & 10 & 5 \\
$\mathbf{1 0}$ & 7 & 1.8 & 6 & 2.2 & 4 & 12 & 6 \\
$\mathbf{1 1}$ & 7 & 1.6 & 5 & 1.6 & 4 & 10 & 4 \\
$\mathbf{1 2}$ & 6 & 2.4 & 5 & 2.2 & 5 & 12 & 3 \\
$\mathbf{1 3}$ & 6 & 2.2 & 4 & 2.2 & 5 & 11 & 4 \\
$\mathbf{1 4}$ & 6 & 1.6 & 4 & 1.6 & 5 & 15 & 6 \\
$\mathbf{1 5}$ & 6 & 2.0 & 5 & 2.4 & 4 & 8 & 3 \\
$\mathbf{1 6}$ & 7 & 2.4 & 6 & 1.8 & 8 & 16 & 7 \\
$\mathbf{1 7}$ & 4 & 2.2 & 5 & 2.8 & 5 & 11 & 4 \\
$\mathbf{1 8}$ & 10 & 2.4 & 8 & 2.2 & 3 & 11 & 4 \\
$\mathbf{1 9}$ & 6 & 1.8 & 6 & 2.0 & 5 & 11 & 6 \\
$\mathbf{2 0}$ & 9 & 2.4 & 7 & 2.0 & 4 & 13 & 6 \\
$\mathbf{2 1}$ & 7 & 1.8 & 4 & 2.0 & 6 & 12 & 2 \\
$\mathbf{2 2}$ & 6 & 2.2 & 4 & 2.0 & 5 & 12 & 5 \\
$\mathbf{2 3}$ & 5 & 2.4 & 5 & 1.8 & 5 & 11 & 5 \\
$\mathbf{2 4}$ & 7 & 2.4 & 7 & 2.5 & 4 & 12 & 5 \\
$\mathbf{2 5}$ & 5 & 2.2 & 4 & 2.0 & 4 & 14 & 7 \\
$\mathbf{2 6}$ & 7 & 1.8 & 5 & 1.8 & 5 & 11 & 5 \\
$\mathbf{2 7}$ & 7 & 2.2 & 5 & 2.0 & 5 & 12 & 6 \\
$\mathbf{2 8}$ & 8 & 2.6 & 7 & 2.0 & 5 & 17 & 9 \\
$\mathbf{2 9}$ & 7 & 2.0 & 6 & 2.0 & 6 & 16 & 9 \\
$\mathbf{3 0}$ & 7 & 2.2 & 6 & 2.8 & 8 & 18 & 10 \\
& & & & & & & \\
\hline Mean & 6.5 & 2.0 & 5.3 & 2.0 & 4.7 & 11.9 & 5.3 \\
Range & $4-10$ & $1.5-2.6$ & $3-8$ & $1.2-2.8$ & $3-8$ & $7-18$ & $2-10$ \\
\hline & & & & & & & \\
\hline
\end{tabular}


Table 5. Measurements of buffalo teats (cm)

\begin{tabular}{|c|c|c|c|c|c|c|c|}
\hline \multirow{2}{*}{$\begin{array}{c}\text { Buff. } \\
\text { No. }\end{array}$} & \multicolumn{2}{|c|}{ Fore teats } & \multicolumn{2}{|c|}{ Rear teats } & \multicolumn{3}{|c|}{ Distance between teats } \\
\hline & Length & Diameter & Length & Diameter & Fore-Rear & Fores & Rears \\
\hline 1 & 9 & 2.6 & 10 & 2.4 & 3 & 7 & 4 \\
\hline 2 & 7 & 2.5 & 7 & 2.0 & 5 & 7 & 2 \\
\hline 3 & 8 & 2.2 & 11 & 3.2 & 3 & 8 & 6 \\
\hline 4 & 5 & 2.0 & 7 & 1.6 & 5 & 12 & 4 \\
\hline 5 & 4 & 2.2 & 6 & 2.0 & 6 & 12 & 4 \\
\hline 6 & 6 & 2.8 & 5 & 2.4 & 3 & 11 & 5 \\
\hline 7 & 5 & 1.6 & 5 & 2.0 & 4 & 7 & 4 \\
\hline 8 & 7 & 2.0 & 7 & 1.4 & 6 & 6 & 3 \\
\hline 9 & 6 & 1.6 & 5 & 2.2 & 7 & 9 & 5 \\
\hline 10 & 6 & 2.0 & 6 & 1.8 & 5 & 8 & 2 \\
\hline 11 & 5 & 1.8 & 5 & 2.4 & 5 & 13 & 5 \\
\hline 12 & 4 & 2.0 & 5 & 2.0 & 4 & 7 & 3 \\
\hline 13 & 5 & 1.8 & 6 & 1.8 & 4 & 9 & 4 \\
\hline 14 & 4 & 1.2 & 5 & 1.8 & 5 & 7 & 4 \\
\hline 15 & 7 & 2.4 & 5 & 2.0 & 4 & 11 & 6 \\
\hline 16 & 6 & 2.8 & 5 & 2.4 & 4 & 9 & 7 \\
\hline 17 & 6 & 2.0 & 6 & 2.4 & 4 & 9 & 4 \\
\hline 18 & 6 & 1.8 & 6 & 2.2 & 3 & 7 & 4 \\
\hline 19 & 4 & 2.2 & 4 & 2.0 & 4 & 11 & 5 \\
\hline 20 & 6 & 1.8 & 7 & 2.4 & 3 & 9 & 7 \\
\hline 21 & 6 & 1.6 & 5 & 1.8 & 4 & 8 & 5 \\
\hline 22 & 6 & 2.6 & 7 & 2.9 & 5 & 11 & 4 \\
\hline 23 & 6 & 2.8 & 6 & 2.8 & 5 & 10 & 6 \\
\hline 24 & 7 & 2.7 & 8 & 2.5 & 7 & 10 & 7 \\
\hline 25 & 7 & 3.0 & 7 & 3.0 & 5 & 10 & 7 \\
\hline 26 & 9 & 2.4 & 7 & 3.4 & 4 & 9 & 3 \\
\hline Mean & 6.0 & 2.2 & 6.3 & 2.3 & 4.7 & 9.0 & 4.6 \\
\hline Range & $4-9$ & $1.2-3.0$ & 4-11 & $1.4-3.4$ & $3-7$ & $6-13$ & $2-7$ \\
\hline
\end{tabular}

\section{Anatomical features of the udder:}

\section{1- Teat wall :}

The teat wall was very thick in buffaloes being double to that of Friesian followed by that of Egyptian cattle, 10, 5 and $8 \mathrm{~mm}$., respectively (Plate 1). This species and breed differences in the teat wall is related to the differences in the skin thickness in buffaloes and Egyptian cattle as reported by Shafie (1954) and (1985) and Hafez et al. (1955), 6, 5 and $4 \mathrm{~mm}$., respectively. Moreover, Friesians had thin walled teats in comparison to the thickness of the skin as reported by Dowling (1955). 


\section{Teat cistern and canal :}

The teat cistern was the largest in buffaloes followed by Friesian than Egyptian cattle (Plate 1). The buffaloes also had the longest teat canal, the average length of the canal was 13, 12 and $9 \mathrm{~mm}$. in buffaloes, Egyptian cattle and Friesian, respectively. McDonald (1968) and Uppal et al. (1995) found that the canal length of fore and rear quarters were 10.7 and $10.9 \mathrm{~mm}$., respectively. The measurements of wall thickness and the canal length showed the same values for the four teats in each individual. This short length of the canal in Friesian could help in facilitating the release of milk during the milking process, especially that the whole length of the ducts in the three breeds is surrounded by controlling sphincter muscle. Loppnow (1959) and Folly et al. (1973) stated that the teats of cows with a low speed of milk flow usually have longer teat canals than cows with a high speed of milk flow. Ragab et al. (1969) and Shafie et al. (1969) reported longer milking time for buffaloes than Friesian, 8.7 and $5.1 \mathrm{~min}$. for morning and evening milking of buffaloes versus 6.4 and $4.6 \mathrm{~min}$. for Friesian, respectively. The species difference in milking time was not corresponding to milk yield which was greater by Friesian, 6.3 and $4.0 \mathrm{~kg}$ in morning and evening milkings versus 5.5 and $2.5 \mathrm{~kg}$ for buffaloes, respectively. Consequently the rate of milking varied, being around $1 \mathrm{~kg} / \mathrm{min}$. for Friesian versus $0.5 \mathrm{~kg} / \mathrm{min}$. for buffaloes. The Egyptian cattle had milking time almost equal to Friesian, 6.38 and $4.6 \mathrm{~min}$., respectively with a rate equal to buffaloes $(0.5 \mathrm{~kg} / \mathrm{min})$ due to less milk yield (4.2 and $1.7 \mathrm{~kg}$; respectively).

\section{3- Gland cistern:}

Friesian possessed a well defined cavernous cistern, into its surface open a number of ducts, the milk ducts (Plate 2), similar pattern was found in native cattle (Plate 2). On the contrary, the buffaloes cistern showed several interceptions of large ducts with elastic thin walls, thus forming numerous pockets instead of a single cavity cistern (Plate 2). Could this pockets and septa delay the milk descent from the cistern to the teat?. The larger milk ducts were generally short and wide in all udders of the three breeds. The branching and direction of the ducts were very irregular in all cases. Although, the udders were full with milk (unmilked) the cisterns and large ducts were empty. The larger ducts were folded. These structural features support the physiological findings reported by Aliev (1969) that milk was expelled from the alveoli only during active milk ejection in buffaloes. 


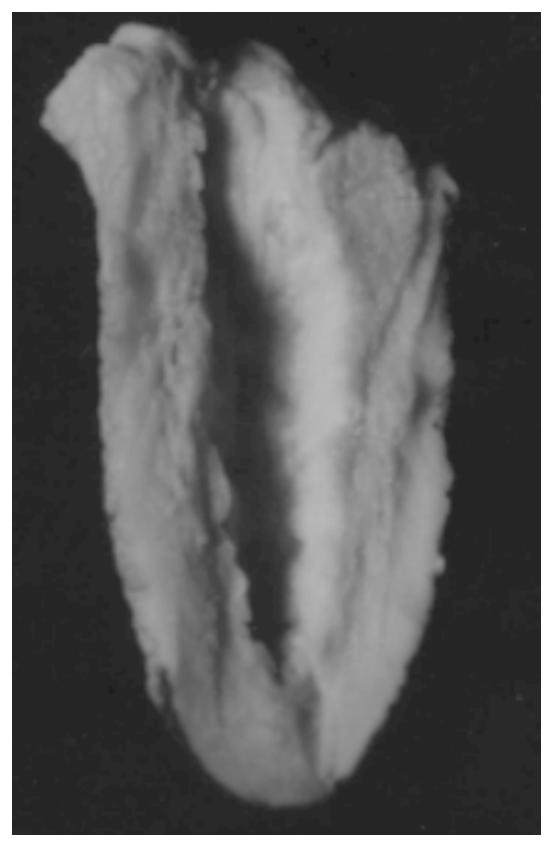

Friesian

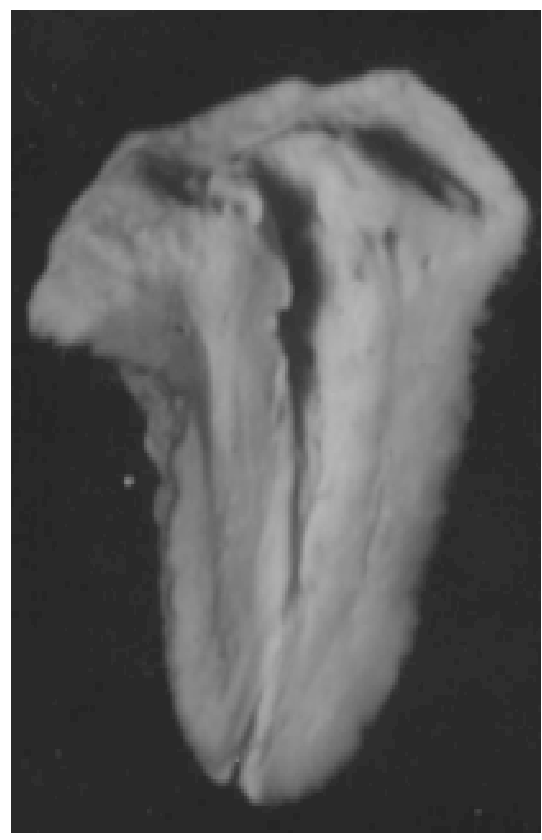

E. Cattle

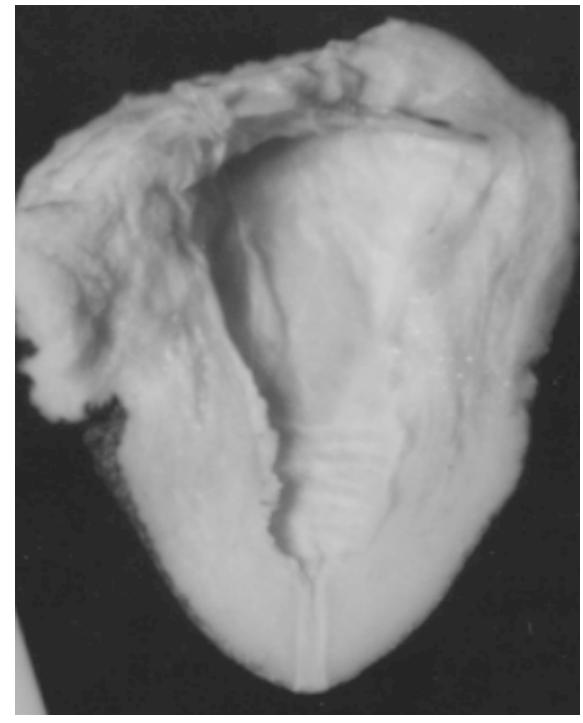

Buffalo

Plate 1. Longitudinal section in the teats of the three breeds showing teat wall, cistern and canal 


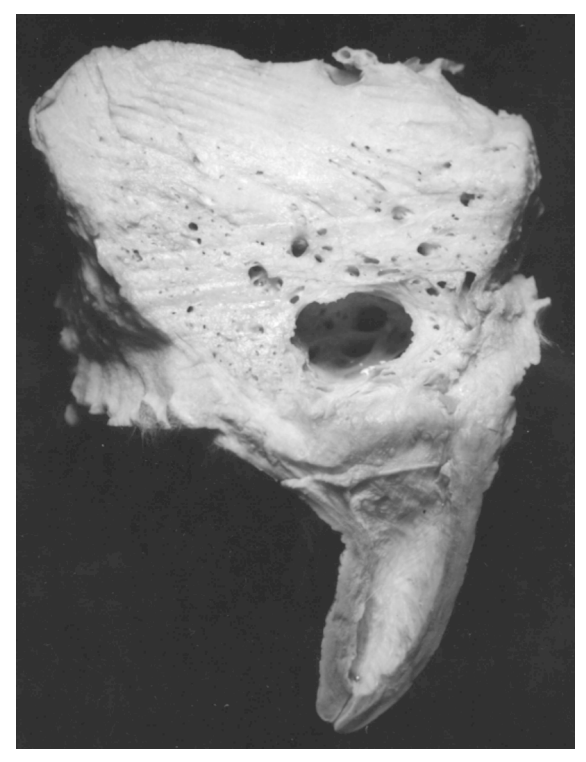

Friesian

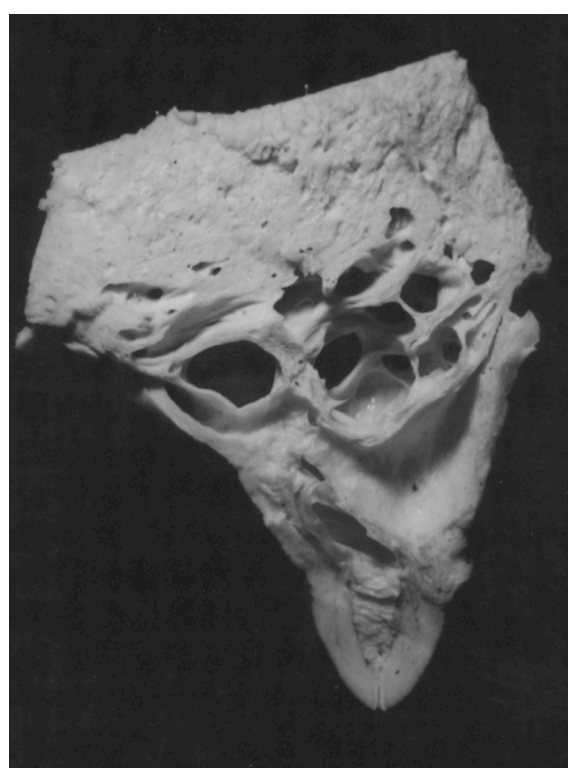

E. Cattle

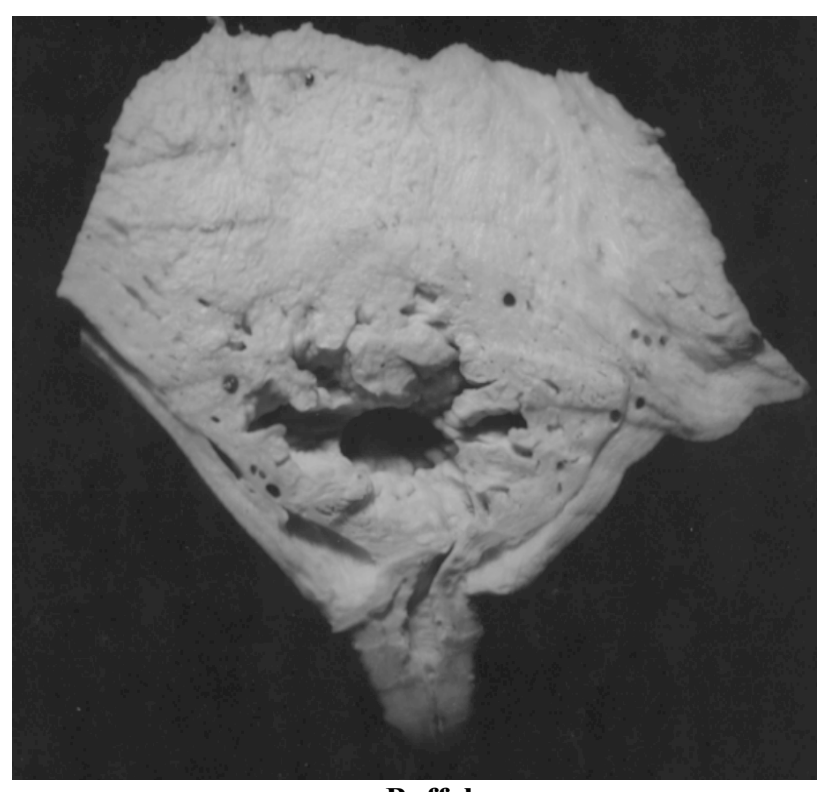

Buffalo

Plate 2. The mammary gland cistern and collecting ducts in the three breeds 


\section{4- Vascular syste :}

The vascular system showed a general picture in the three types of animals, with some variations in the branching of the main arteries and veins (Plate, 3).

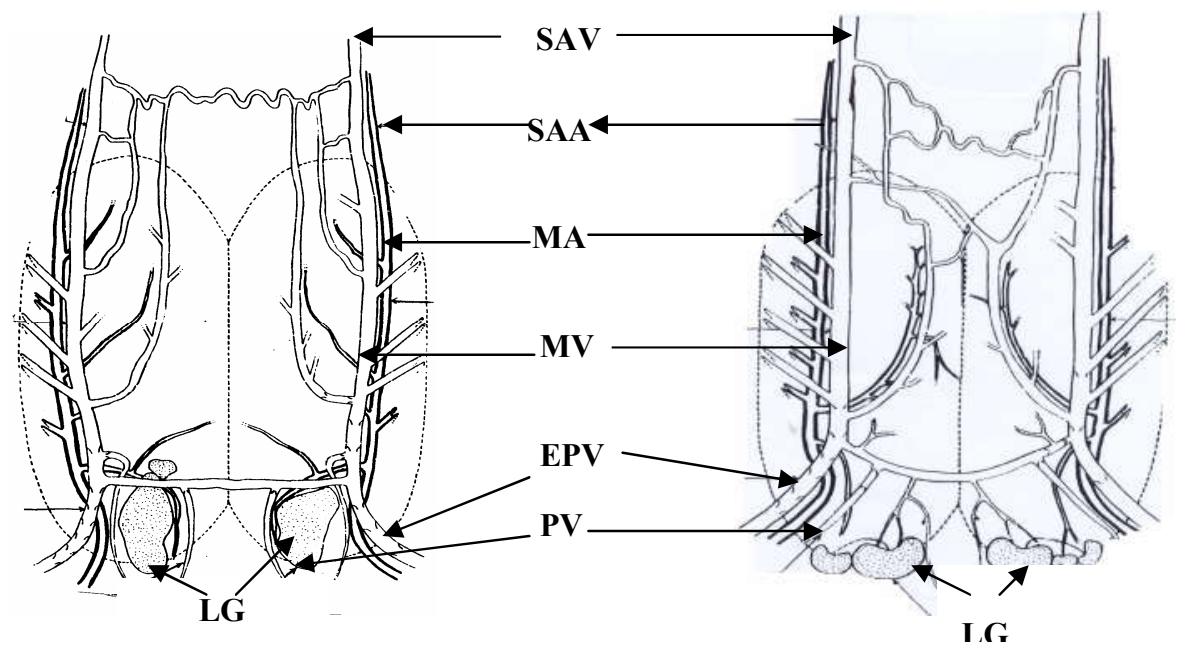

Friesian

E. Cattle

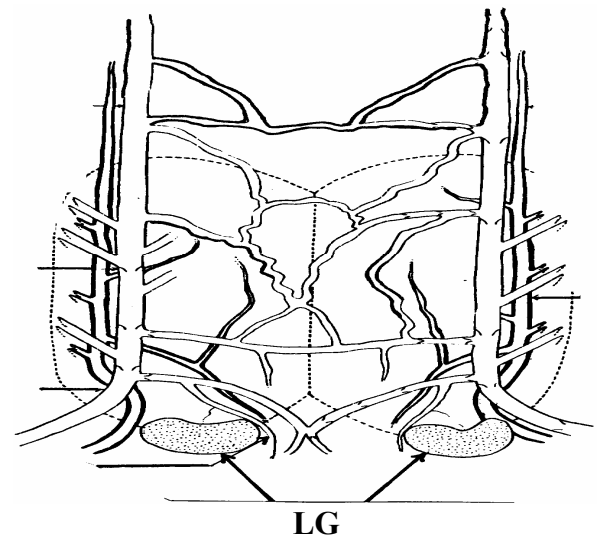

Buffalo

Plate 3. Main blood vessels of the udders in the three breeds

(MV) Mammary vein, (EPV) External pudic vein,(LG) Lymph gland

(MA) Mammary artery, (PV) Perineal vein, (SAA) Subcutaneous abdominal artery,

(SAV) Subcutaneous abdominal vein 


\section{1- Venous system :}

The mammary venous system consisted of the two major longitudinal veins which connect the external pudic with the subcutaneous abdominal vein on the corresponding sides. These major veins were connected by transverse large veins in the posterior and anterior parts of the udder. The posterior connection was located just in front of the supramammary lymph glands. The anterior connecting veins were more numerous and prominent in buffaloes than in both of the cattle breeds. The buffaloes possessed numerous large branches in the venous system connecting the circulation in the two halves, right and left, of the udder. Friesians and native cattle showed less large branches from the main veins (Plate 3). This difference in the branching of large veins may be effective in the blood flow in the udder. The numbers and locations of the valves in the large veins of the mammary venous plexus showed wide variation between breeds and even between individuals within breed. It is questionable to notice from the direction of the valves in the perineal vein that it is not draining the udder but is bringing blood towards the udder. The direction of the valves in the transverse connecting veins insure the distribution of the venous blood between the major veins on both halves of the udder.

\section{2-Arterial system :}

There was no difference between the species and breeds in the main arteries. In all cases, the udder lacked any conspicuous direct connection of the main arteries between its two halves (Plate 3).

\section{5- Lymph glands :}

The shape and lobulation of the supramammary lymph gland showed clear species differences (Plate 3). Buffaloes possessed non lobulated glands, in one buffalo it was disc shaped, in the other kidney shaped. The cattle breeds had lobulated glands formed of separate lobules, one of the lobule, however, is large enough to provide the majority of the gland (Plate 3). Individual variation within breed was clear in the size and lobulation of the gland. Moreover, there was clear difference between the halves of the udder in the number and location of the lobules.

\section{REFERENCES}

Aliev, M. G.. 1969. Physiology of milk ejection in buffaloes. Dairy Sci., Abst., 31:677-680.

Buben, D. M., 1969. Morphological and physiological characters of the udder of cows of the Russian Blacv-Pied breed and White-Russian Red breed group. Dokl Tinniryozev - Sel'Skoz - Aked., Mosk., No. 151 : 23-28 (Anim. Breed. Abst., 38:1153.

Dowling, D. F. 1955. The thickness of cattle skin. Aust. J. Agric. Res., 6:776-785.

Folly, R. C., D.L. Bath , F. N. Dickinson and H. A. Tucker, 1973. Dairy Cattle: Principles, Practices, Problems, Profits. Lea and Febiger, Philadelphia, USA, pp. 352-389.

Garkavijs, F., L. Amba and A. Sennikova, 1965. The improvement and evaluation for selection of the udder of Latvian Red Cows. Anim. Breed. Abst., 35:130.

Hafez, E. S. E., A.L. Badreldin and M.M. Shafie, 1955. Skin structure of Egyptian buffaloes and cattle with particular reference to sweat glands. J. Agric. Sci., 46:20-30. 
Hladky, J., 1964. Udder and teat measurement in relation to the milk production of cows in the foothills. Anim. Breed. Abst., 32:1879.

Loppnow, H., 1959. Influence of teat structure on milking ability. Dairy Sci. Abst., 22:2229.

McDonald, J. S., 1968. Radiographic method for anatomic study of the teat canal : Observations on 22 lactation dairy cows. Dairy Sci. Abst., 30:3063.

Nowak, T., 1969. Udder shape in Polish Black and White low land cows. Dairy Sci. Abst., 32:1414.

Ragab, M. T. M.M. Shafie and M. Kilani, 1969. Milk yield and milking rates of the individual quarters of the udder in buffaloes, Egyptian cows and Friesian cows. Egyptian J. Anim. Prod., 9:67-78.

Shafie, M. M., 1954. Skin histology of Egyptian buffaloes and cattle with particular reference to sweat glands. M. Sc. Thesis, Fac. Agric., Cairo Univ., Giza, Egypt.

Shafie, M. M., 1985. Physiological responses and adaptation of water buffalo. In : Stress physiology in Livestock. M. K. Yousef (Ed.) Vol.1. pp. 67-80. CRC Press, Boca Raton, Florida.

Shafie, M.M., M.T. Ragab and M. Kilany, 1969. Milking time and initial milk yield in buffaloes, Egyptian cattle and Friesian cattle. Egyptian J. Anim. Prod., 9:211219.

Suzuki, S., S. Oota, N. Kado and N. Iwao, 1963. On the variation in the udder size of dairy cows : Relationships between udder size and milk yields. Dairy Sci. Abst., 25:1569.

Uppal, S. K., K.B. Singh, B.K. Bansal, D.C. Nariyal and K.S. Roy, 1995. Histomorphological study on the teat (mammary papilla) of Indian buffalo. Indian J. Anim. Sci., 65:853-856. 


\section{دراسة مقارنة لتركيب الضرع في الجاموس والابقار ا- الخصائص المورفولوجية والتشريحية للغدة اللبنية}

صفاء سعيد الغصين'، محمد محمود الثافعي'، جمال عاشور ' وعبد اللطيف بدر الدين'

1 - كلية الزراعة والعلوم، جامعة جرش الاهلية، جرش، الأردن، ؟ - قسم الانتاج الحيواني، جامعة القاهرة،

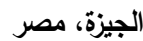

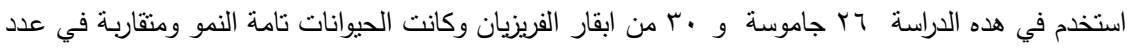

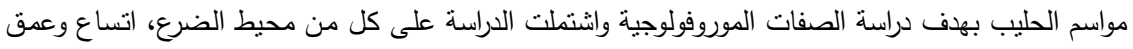

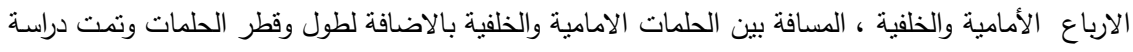

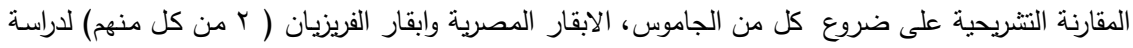

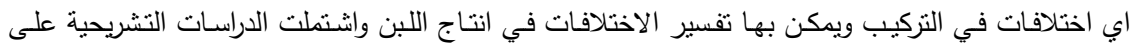
خصائص تركيب الحلمة (كل من سكك الجدار ، ومحزن وقناة الحلمة) ، محزن الغدة، الامداد الدموي (الثرياني والوريدي) والغدة الليمفاوية.

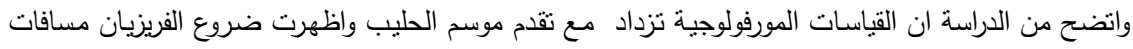

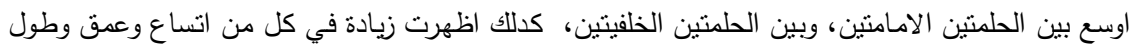

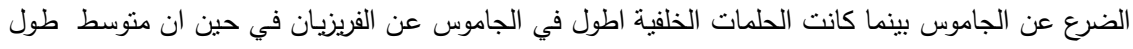

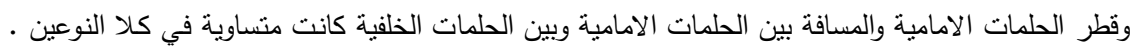

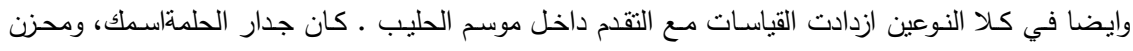

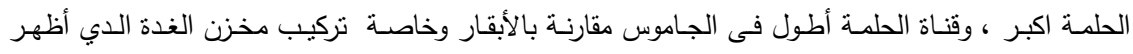

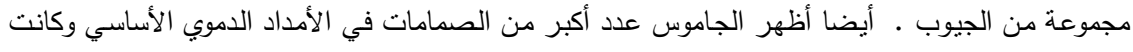

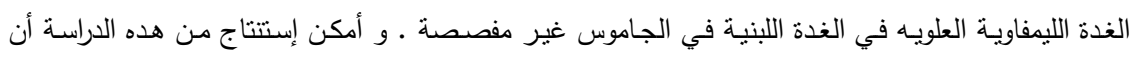

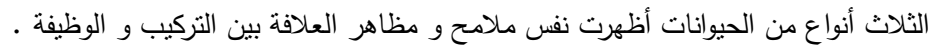

